\title{
ПОЛИТИЧЕСКИЕ HАУКИ
}

УДК:327

ГРНТИ:11.15.86

\section{СОВРЕМЕННАЯ УКРАИНА КАК ГОСУДАРСТВО-ЛИМИТРОФ}

DOI: 10.31618/ESU.2413-9335.2020.6.72.658

Родин Илья Олегович

Московский государственный лингвистический университет

Студент IV курса

\author{
Ilya Rodin \\ Moscow State Linguistic University \\ $4^{\text {th }}$ year student
}

\section{АННОТАЦИЯ}

Феномен государства-лимитрофа вновь стал актуальным после распада Советского союза в 1991 году, когда на окраинах России стали образовываться новые независимые государства. Данный вопрос был рассмотрен отечественными исследователями, однако на данном этапе эта по-прежнему релевантная тема несправедливо обделена вниманием в политическом дискурсе. В этой статье автор постарается определить, какую роль государства-лимитрофы играют в мировой политике, а также каким образом лимитрофизация влияет на внешнюю и внутреннюю политику Украины.

\section{ABSTRACT}

The phenomenon of the state of limitrophe became relevant once again after the collapse of the Soviet Union in 1991, when new independent states began to form on the frontiers of Russia. This issue has been researched by domestic scholars, but at this point this still important topic is unfairly overlooked in the political discourse. In this article, the author tries to determine what role limitrophe states play in world politics, as well as how limitrophization affects Ukraine's foreign and domestic policy.

Ключевые слова: лимитроф, государство-лимитроф, геополитическая технология, комплекс лимитрофа, массовое сознание, Украина.

Keywords: limitrophe, state-limitrophe, geopolitical technology, limitrophe complex, collective consciousness, Ukraine.

Государства-лимитрофы играют часто незаметную роль на мировой арене. Они выражают готовность поступиться частью суверенитета и выгодно продать собственную геополитическую ориентацию любому конкурирующему государству. Сейчас использование лимитрофов превратилось в особую геополитическую технологию по оказанию влияния и воздействия на конкретную страну. При этом для того, чтобы назвать страну лимитрофом в массовом сознании её граждан должны сформироваться определённые психологические установки, так называемый «комплекс лимитрофа». Пример Украины как государства-лимитрофа является одним из наиболее наглядных. Во многом это поможет с иной точки зрения рассмотреть российскоукраинские отношения.

Термин «limitrophus» (граничащий с чем-либо) впервые был употреблен в Римской империи. В то время он использовался для описания пограничных с Римом варварских земель, которые поставляли провизию, ресурсы и вооружение, а также содержали на своей территории специальные подразделения императорских войск - лимитанов. В дальнейшем термин стал более узконаправленным и применимым, как правило, в геополитическом дискурсе.

Позже лимитрофами называли новые образованные государства после распада Российской империи в 1917 году (Финляндия,
Польша, Эстония, Латвия, Литва). А окончательно термин закрепился в российском научном дискурсе после развала Советского союза в 1991 году для обозначения части новых независимых государств на постсоветском пространстве. Также нередко под странами-лимитрофами понимается «санитарный кордон» вокруг России, с помощью которого другие государства оказывают воздействие на нашу страну. С иной точки зрения можно охарактеризовать лимитрофы как группу «буферных государств» по терминологии Дж. Керзона или вид «критических границ» по терминологии К. Боулдинга [5].

В современный научный оборот термин «лимитрофное государство» вернулся благодаря трудам российского историка, философа, филолога и специалиста по геополитике В.Л. Цымбурского. В своей работе «Земля за Великим Лимитрофом: от «России-Евразии» к «России в Евразии» В.Л. Цымбурский выдвигает теорию о том, что Россию окружает пояс государств-лимитрофов, появившихся на карте после распада СССР [8]. Согласно учёному в эту группу государства входят Финляндия, Прибалтика, страны Восточной Европы, Кавказ, Центральная Азия, Монголия, а также Корейский полуостров. При это по мнению В.Л. Цымбурского ни одна из стран-лимитрофов полностью не консолидирована в какую-либо из состоявшихся цивилизаций. 
Одновременно с В.Л. Цымбурским другой российский учёный С.В. Хатунцев стал заниматься исследованием стран-лимитрофов. Он разделял идею своего коллеги о том, что Россию окружает пояс государств-лимитрофов, однако взгляды на то, какие именно страны входят в этот пояс, несколько разнились. С.В. Хатунцев включал в Великий лимитроф намного меньше стран Восточной Европы, но добавлял туда Афганистан, Пакистан, Курилы и Аляску. Также он считал, что не только Россия, а каждая мировая цивилизация окружена поясом лимитрофов или естественным водным барьером. Таким образом, С.В. Хатунцев определил три метацивилизации и странылимитрофы, разделяющие их: метасистема Европа - Россия; Китай - Индия; арабо-персидский мир Черная Африка [7].

Однако автору данной статьи представляется, что в XXI веке содержание термина «лимитроф» несколько изменилось. Исходя из работ В.Л. Цымбурского и С.В. Хатунцева, а также исследований других учёных, можно вывести интегративное определение государствалимитрофа. Государство-лимитроф - это пограничное, де-юре независимое государство, добровольно испытывающее влияние и являющеюся сателлитом другой страны.

Использование лимитрофных государств представляет собой геополитическую технологию, которой применяют как демократические, так и тоталитарные страны. При этом сейчас её используют не только страны-гегемоны, но и негосударственные акторы, такие как транснациональные корпорации и неправительственные организации. Целью же использования лимитрофа является экономия сил, чтобы избежать прямого столкновения с потенциальным противником, или же защита и расширение собственного влияния на конкретный регион или страну. Грубо говоря, использование лимитрофа позволяет государству действовать чужими руками.

Не стоит забывать, что лимитрофное государство - это всегда чей-то лимитроф, контролируемый кем-то и организуемый не столько вблизи собственных границ, сколько на территориях, которые не являются пограничными на данный момент, однако расцениваются в качестве крайних точек защиты (и, при этом, базовых точек распространения далее) приемлемых для себя культурно-духовных ценностей, а также нравственно-поведенческих образцов [9].

При этом государство лимитроф - это не только геополитический феномен, но, кроме того, и политико-психологический.

Лимитрофизация стран протекает чаще из-за внутренних, а не внешних причин [10]. Процесс трансформации страны в лимитроф включает в себя политические, социальные, исторические, культурные и психологические причины. В массовом сознании граждан государства-лимитрофа со временем начинает формироваться «комплекс лимитрофа». Он представляет собой некую политическую ментальность, имманентным качеством которой является комплекс неполноценности, нереализованности. Государственные элиты странлимитрофов используют различные бессознательные механизмы психологической защиты, такие как подавление, интеллектуализация, компенсация, отрицание реальности и другие [1]. Подобная линия поведения, использования методов психологической защиты во внешней политике, может негативно сказаться как на образе страны, так и на дальнейшем политическом развитии государства.

Современная Украина представляет собой наиболее яркий пример лимитрофного государства. Можно сказать, что Украина в 1991 году сразу родилась лимитрофом, хотя, безусловно, не мало исторических событий способствовало лимитрофизации Украины. Само украинское общество, психология поведения оказали влияние на её трансформацию в страну-лимитроф. Следовательно, общество Украины подвержено «комплексу лимитрофа», что сказывается как на внутренней, так и на внешней политике государства.

Говоря о географическом положении страны, стоит заметить, что Украина и сейчас находится на стыке двух культурных типов: византийскорусского и польско-украинского, что стимулирует внутреннюю конфликтогенность и напряжённость. Характерным признаком южнославянских племён ещё во времена Древней Руси, во многом как и сейчас, было то, что государственными и руководящими делами занималась «шайка воинственных разбойников», представлявшую собой смесь различных племён и инородцев. Развитие личного произвола, свобода, неопределенность форм - были отличительными чертами южнорусского общества в древние периоды, и так оно явилось впоследствии. В то время как для великорусской народности главной опорой государственности был общественный порядок, то в Киеве тщетно было бы искать какогонибудь определенного права и порядка [6]. Следовательно, доказав свою неспособность и безразличие к собственному государственному устрою, южнославянское племя должно было присоединиться к великорусскому, в то время как его главной целью было создание централизованного государства. Однако исторически судьба украинского народа переплетается с польским, что в конечном счёте повлияло на сознание украинского народа.

Испокон веков Украина была расположена на периферии более крупных и сильных государств. Данный факт в значительной степени имел воздействие на политическое сознание и поведение людей. Прежде всего, это пагубным образом сказалось на выстраивании унификационных моделей, идентичности, культурных и государственных норм. Кроме того, среди украинских элит наблюдается комплекс несамодостаточности и нереализованности. 
Политическая элита Украины регулярно проводит параллели и сопоставляет свои действия с действиями руководства Российской Федерации, что время от времени обретает форму навязчивой идеи [4]. Для Украинского государства свойственно отсутствие твёрдой политики, некая переменчивость и неустойчивость на пути к достижению долгосрочной цели. Украинские политики имеют тенденцию одновременно к созданию и разрушению созданного [6]. Всю жизнь боровшись с Польшей, Литвой, Россией и другими странами за незалежність, украинская элита снова оказалась неспособна построить независимое государство.

В 1991 году украинская политическая элита получила возможность построить новое независимое государство. Однако за почти 30 прошедших лет Украина научилась только имитировать государственность на фоне упадка культурных, социальных, политических и экономических сфер жизни. Оказавшись вырванной из тела СССР, Украина пытается функционировать как отдельный орган [2]. Государственная элита мыслит категориями провинциальной страны и с каждым годом становится всё более некомпетентной и беспомощной.

Однако несправедливо по этому поводу возлагать вину только на украинскую элиту, ведь «комплексу лимитрофа» подвержено всё украинское общество. К примеру, отношение украинцев к России строится на негативных аффектах, старых обидах, ненависти и зависти, что можно интерпретировать как неумение работать с причинно-следственными связями и неспособностью к рефлексии.

Одним из основных критериев «комплекса лимитрофа» являются попытки избегания ответственности и перекладывание вины на кого-то другого. По отношению к России это проявляется в обилии различных обвинений как серьёзных, так и абсурдных, начиная от Голодомора и заканчивая «газовым вопросом». Это может наблюдаться как во внешнеполитической линии страны, так и у рядовых граждан. С точки зрения психологии у них наблюдается экстернальный локус контроля, то есть для них характерно отрицать собственные ошибки и неудачи и искать причину своих бед во внешних обстоятельствах.

В стране-лимитрофе люди в большинстве своём не обременены критическим мышлением, сомнениями, формированием собственных, а не навязанных убеждений и ориентиров. Украинский народ живёт в царстве теней и борется с тенями, что может быть вполне естественно ведь Украина находится между Западом и Россией. «В этой вечной нашей борьбе против хаоса на Востоке, в обороне - в своей собственной государственности и культуре - целой культуры Запада, как раз и заключается украинская национальная идея, долженствующая быть основанием целой нашей политической программы» [3].
Рассмотрев концепцию лимитрофного государства, можно прийти к следующим заключениям. Прежде всего, лимитрофные государства являются геополитической технологией, неким инструментом в руках странгегемонов. Они используют лимитрофы с целью защиты своей страны от вредоносного влияния, или, напротив, для расширения и экспансии своего воздействия, культурных ценностей. Кроме того, лимитрофизация происходит в тех государствах, где массовое сознание граждан вследствие исторических, социальных, культурных и психологических причин подвержено «комплексу лимитрофа». Во многом ответственность за лимитрофизацию несёт национальная элита страны, которая с лёгкостью меняет линию поведения из-за тщеславия и личной выгоды. Пример Украины наглядно иллюстрирует как страна всеми силами пытается обвинить Россию и другие государства в собственных проблемах ошибках, выступая в качестве жертвы. Потеряв политическую субъектность, Украина стала инструментом в руках Запада для сдерживания России.

\section{Список литературы:}

1.Бухарин С.Н., Ракитянский Н.М. Россия и Польша. Опыт политико-психологического исследования феномена лимитрофизации. М.: Институт русской цивилизации, 2011. С.14

2.Ваджра А. РАСПАД: Украинский лимитроф в геополитическом раскладе Евразии-1 // Информационно-аналитический портал «Альтернатива» URL: http://alternatio.org/articles/item/2827 (дата обращения: 03.04.2020)

3.Донцов Д. Твори. Т.I. Геополітичні та ідеологічні праці / О. Баган (упоряд., передмова, комент.); Інститут української археографії та джерелознавства ім. М. Грушевського НАН України. Львів: Кальварія, 2001. С. 144

4.Зоткин А.А. Отношение украинцев к России и россиянам до и во время гражданского конфликта 2014 г. // Актуальные проблемы Европы. 2015. №2. C. 94-108

5.Комлева Н.А. Лимитроф в современном геополитическом процессе // Электронное научное издание Альманах Пространство и Время. 2013. Т.3. Вып.1

6.Костомаров Н.И. Две русские народности. Киев, 1991. 72 с

7.Хатунцев С.В. Новый взгляд на развитие цивилизаций и таксономия культурноисторических общностей // Цивилизационный подход к истории: проблемы и перспективы развития. Ч.1. Воронеж, 1994

8.Цымбурский В.Л. Земля за Великим Лимитрофом: от «России-Евразии» к «России в Евразии» // «Бизнес и политика», 1995, № 9

9.Шульга М.А. О лимитрофе: духовноорганизационный аспект (на примере Украины) // Россия: тенденции и перспективы развития. Ежегодник. 2017. Вып.12, ч.3. С.211-222 
10.Юрьев А.И. Феномен лимитрофизации как ведущий инструмент внешнеполитического воздействия на Россию // Проблемный анализ и

УДК:32.019.5

ГРНТИ:11.15.19 государственно-управленческое проектирование. 2011. №6. C.142

\title{
СПЕЦИФИКА ФОРМИРОВАНИЯ ВНЕШНЕПОЛИТИЧЕСКОГО ОБРАЗА УКРАИНЫ В СМИ США
}

DOI: $10.31618 /$ ESU.2413-9335.2020.6.72.659

Цыркина И.А.

Московский Государственный Лингвистический Университет

Студентка IV курса

\section{THE SPECIFICS OF FORMING A FOREIGN POLICY IMAGE OF UKRAINE IN THE U.S. MEDIA}

\author{
Irina Tsyrkina \\ Moscow State Linguistic University \\ 4th year student
}

\begin{abstract}
АННОТАЦИЯ
Данная статья посвящена исследованию специфики формирования внешнеполитического образа в современной мировой политике, а именно, образа Украины в СМИ США. Также работа обусловлена увеличившимся использованием методов и технологий формирования внешнеполитического образа государства на уровне современной мировой политики. В настоящее время распространено мнение о том, что СМИ занимают одно из главных мест в современном политическом процессе, поэтому они могут оказывать значимое влияние, как на образ, так и на внешнеполитическую деятельность государства в сознании масс своей страны и мировой арены, в целом.

\section{ANNOTATION}

This article is devoted to the research of the specifics of forming a foreign policy image in modern world politics, notably, the image of Ukraine in the U.S. media. The work is also attributable to the intensified use of methods and technologies for forming the foreign policy image of the state at the level of modern world politics. Currently, there is a widespread perception that the media occupy one of the main places in the modern political process, so they can have a significant effect on the image and foreign policy of the state in the consciousness of the masses of their country and the world stage as a whole.
\end{abstract}

Ключевые слова: внешнеполитический образ, общественное мнение, образ Украины, масс-медиа, СМИ США.

Keywords: foreign policy image, public perception, image of Ukraine, mass media, the U.S. media.

На данный момент Украина, происходящие события внутри государства, и проводимая ею внешнеполитическая и внутриполитическая деятельность, являются актуальными вопросами для обсуждения в глазах мировой общественности. Данные темы подвергаются спорам и конфликтам со стороны политологов, а также политиков и независимых экспертов. Сегодня практически любую информацию мы можем получить через СМИ, в свою очередь СМИ являются неким конструктором и репрезентатором различного рода информации, в том числе и материала, касающегося вопросов политики государств и их жизни, в целом. Украинский вопрос занимает существенное место в современном политическом межгосударственном диалоге, актуальным является исследование образа Украины в средствах массовой информации США.

Также в свете произошедшей революции и постреволюционных процессов на Украине, важно анализировать эти события такими, какими они предстают в иностранных СМИ, в частности американских, поскольку они влияют на создание общественных убеждений и принятия политических решений США.
Стоит отметить, что государственные и революционные события в Украине активизировали процесс освещение новостей об Украине в СМИ других стран. Следует отметить, что в постреволюционный период, - свержение режима Януковича 22 февраля и в период дальнейшей смены правления Украины, в частности, и политического курса, в общем, начали появляться исследования об образе Украины в СМИ европейских государств и США, которые показали кардинальные изменения восприятия Украины за рубежом.

В целом, отражение в новостях США информации о событиях в Украине можно отметить как значимое для последней, поскольку, по мнению К. Боулдинга, политика в целом, а особенно ее внешнеполитическая составляющая, позволяют запустить «процесс формирования образа под стимулирующим воздействием сообщений, переданных через средства связи» [10], притом, по мнению исследователя, указанный процесс имеет существенное влияние на ход принятия политических решений.

Взяв за внимание вышеуказанное мнение, можем сказать, что образ государства формируется 